\title{
Propylene Glycol and Non-Destructive DNA Extractions Enable Preservation and Isolation of Insect and Hosted Bacterial DNA
}

\author{
Francesco Martoni ${ }^{1, *} \mathbb{0}$, Elisse Nogarotto ${ }^{1}$, Alexander M. Piper ${ }^{1,2}{ }^{2}$, Rachel Mann ${ }^{1}$, Isabel Valenzuela ${ }^{1}$, Lixin Eow ${ }^{1}$, \\ Lea Rako ${ }^{1}$, Brendan C. Rodoni ${ }^{1,2}$ and Mark J. Blacket ${ }^{1}$ (D) \\ 1 AgriBio Centre for AgriBiosciences, 5 Ring Road, Bundoora, VIC 3083, Australia; \\ elisse.nogarotto@agriculture.vic.gov.au (E.N.); alexander.piper@agriculture.vic.gov.au (A.M.P.); \\ rachel.mann@agriculture.vic.gov.au (R.M.); isabel.valenzuela-gonzalez@agriculture.vic.gov.au (I.V.); \\ Lixin.eow@agriculture.vic.gov.au (L.E.); lea.rako@agriculture.vic.gov.au (L.R.); \\ brendan.rodoni@agriculture.vic.gov.au (B.C.R.); Mark.blacket@agriculture.vic.gov.au (M.J.B.) \\ 2 School of Applied Systems Biology, La Trobe University, Bundoora, VIC 3083, Australia \\ * Correspondence: francesco.martoni@agriculture.vic.gov.au
}

check for updates

Citation: Martoni, F.; Nogarotto, E.; Piper, A.M.; Mann, R.; Valenzuela, I.; Eow, L.; Rako, L.; Rodoni, B.C.; Blacket, M.J. Propylene Glycol and Non-Destructive DNA Extractions Enable Preservation and Isolation of Insect and Hosted Bacterial DNA Agriculture 2021, 11, 77. https:// doi.org/10.3390/agriculture11010077

Received: 3 December 2020

Accepted: 4 January 2021

Published: 18 January 2021

Publisher's Note: MDPI stays neutral with regard to jurisdictional claims in published maps and institutional affiliations.

Copyright: (c) 2021 by the authors. Licensee MDPI, Basel, Switzerland. This article is an open access article distributed under the terms and conditions of the Creative Commons Attribution (CC BY) license (https:// creativecommons.org/licenses/by/ $4.0 /)$

\begin{abstract}
Plant bio-protection and biosecurity programs worldwide use trap-based surveillance for the early detection of agricultural pests and pathogens to contain their incursions and spread. This task is reliant on effective preservation in insect traps, which is required to maintain specimen quality for extended periods under variable environmental conditions. Furthermore, with traditional morphological examinations now increasingly paired with modern molecular diagnostic techniques, insect traps are required to preserve both the specimens' morphology and the DNA of insects and vectored bacterial pathogens. Here, we used psyllids (Hemiptera) and their hosted bacteria as a model to test the preservative ability of propylene glycol (PG): a non-flammable, easily transportable preservative agent that could be used in pitfall, suction or malaise traps. We tested preservation using various PG concentrations, at different temperatures and for multiple time periods, paired with non-destructive DNA extraction methods, which allow isolation of both insect and arbobacterial DNA while retaining a morphological voucher of the insect host specimens. PG concentrations between $40 \%$ and $100 \%$ performed best for both insect and bacterial DNA preservation up to 28 days. Ultimately, given the viscous nature of PG at high concentrations, we recommend using it at a concentration between $40 \%$ and $60 \%$ to enable insects to sink into the solution, thus enhancing DNA preservation.
\end{abstract}

Keywords: psyllids; non-destructive DNA extraction; Candidatus Liberibacter; preservative agents; biosecurity; insect traps

\section{Introduction}

Field surveillance, plant protection and plant biosecurity programs worldwide rely heavily on trap-based surveillance to detect invasive insects and their vectored bacterial pests [1,2]. A number of phloem- and xylem-feeding insects, such as psyllids (Psylloidea) or leafhoppers (Cicadellidae), are considered agricultural pests due to their ability to vector plant pathogenic bacteria causing significant economic losses to crops [3-5]. For example, the tomato potato psyllid Bactericera cockerelli (Šulc 1909) vectors the bacterium Candidatus Liberibacter solanacearum, the causal agent of the Zebra Chip disease that has caused millions of dollars in losses to the tomato and potato industries worldwide [6].

Consequently, the capture and identification of insect pests are critical steps in the early stages of a biosecurity response to insect and arbobacterial (insect-vectored bacteria) incursions. Early and accurate surveillance data is also invaluable in monitoring and managing the movements of established exotic and native pests to prevent their spread [7]. The last twenty years have seen a shift in pest identification techniques, from mostly morphologybased identification to a plethora of modern molecular identification approaches [8]. Such 
a shift in the identification process also requires a re-assessment of methods for insect collection to enable specimen preservation for both morphological and molecular work.

Insects collected for scientific purposes have traditionally been pinned or preserved in diluted ethanol to retain their morphology [9]. Ethanol (70-80\%) has proved useful in the short term for DNA preservations and downstream DNA amplification and sequencing; however, DNA degradation does occur during long term storage [10]. Best practice for DNA preservation includes cold temperatures, freezing at $-80{ }^{\circ} \mathrm{C}$ and $-150{ }^{\circ} \mathrm{C}$ [11], the use of cryoprotectants [12], high concentration ethanol [13] or even dry storage [14]. However, in the context of pest surveillance in remote areas, environmental factors, such as humidity, high and extreme temperature ranges, make the application of some of these preservation techniques quite challenging [15]. Consequently, a wide number of solvents and detergents have been tested over the years for the preservation of DNA under field conditions $[11,13,16-19]$. However, these often involve a trade-off between DNA quality and the morphological integrity of the insect specimen [13]. For example, high concentrations of ethanol (90-100\%) are one of the preferred methods for long-term DNA preservation [20] but can make the specimens shrivel and brittle, often leading to damage of the specimen and challenging morphological identification [13]. Additionally, the use of high-concentration ethanol in trapping situations that are exposed to evaporation can be problematic, e.g., pitfall traps are at risk of drying out in just a few days [21]. Finally, many alcohol-based preservatives, being flammable, incur transport and shipping limitations or are often prohibited.

Propylene glycol (PG) is a synthetic, colourless, odorless, tasteless liquid that is mostly used in the food and cosmetic industries for its moisture-retaining properties. Its widespread use, coupled with it not being flammable, toxic or dangerous, means it could replace ethyl alcohol in situations where this product cannot be used. The capacity of propylene glycol to act as a preservative agent of arthropods has been studied for almost 20 years [22]. It has been tested as a preservative on many different invertebrate groups, including spiders [23], Hymenoptera [14,22], Coleoptera [14,24,25], Diptera [14,26,27] and Psocoptera [28]. Some of these studies tested PG DNA preservation at temperatures as high as $40^{\circ} \mathrm{C}$ [22] or for as long as 10 months [17]. Ferro and Park [25] tested different percentages of PG to understand the effect of dilution, to simulate rain in the field, demonstrating good DNA preservation at PG concentrations greater than $40 \%$ at room temperature.

Based on these works, PG appears to be a suitable candidate for preserving the DNA of trapped insect specimens in remote field sites. However, none of the studies above tested the effect of PG preservation on insect-harbored bacteria, nor did they pair PG preservation with non-destructive DNA extraction methods. Such non-destructive DNA extraction methods allow the retention of morphological vouchers of the specimens analysed for pest diagnostics [29] and can also be used in a metabarcoding analysis, which allows quick and reliable high throughput sequencing identification of pooled samples [8].

The scope of our experiments was to determine the optimal percentage of propylene glycol (PG\%) for the preservation of both insect and bacterial DNA within field traps, testing multiple PG\% at different temperatures and periods of time. Additionally, we wanted to determine if non-destructive DNA extraction methods could successfully detect both insect and associated bacterial DNA preserved in PG while retaining a morphological voucher of the host specimens from which DNA was extracted. To test this, we focused on the non-pest model offered by the Australian native psyllid, Acizzia solanicola Kent \&Taylor 2010 (Hemiptera: Psylloidea), and the non-pathogenic bacterium it harbors, Candidatus Liberibacter brunswickensis (CLbr; [30]). This psyllid can be found on commercial (i.e., eggplants) and non-commercial (i.e., wild tobacco) crops [31]. The bacterium belongs to the genus of known plant pathogenic bacteria, such as $\mathrm{Ca}$. Liberibacter solanacearum [4] and Ca. Liberibacter asiaticus [32], however, is not known to cause diseases [30] and thus, presents a safe model to study gut-associated insect-vectored bacteria.

A quantitative polymerase chain reaction (qPCR) method was utilised for the amplification of insect $18 \mathrm{~S}$ ribosomal DNA (rDNA) and bacterial $16 \mathrm{~S}$ ribosomal DNA using the 
comparative cycle threshold ( $\mathrm{Ct}$ ) method [33] to assess the degradation of insect and bacterial DNA in different propylene glycol percentages stored at various temperatures over time, emulating the varied environmental conditions of typical insect trapping programs.

\section{Materials and Methods}

\subsection{Samples}

A colony of A. solanicola psyllids, infected with the bacterium Candidatus Liberibacter brunswickensis (CLbr), was reared in the Agriculture Victoria Research facilities at the AgriBio Centre for Agribiosciences, La Trobe University campus, Bundoora, Victoria. Psyllids were collected from eggplants (Solanum melongena) in January 2015 in Brunswick East, Victoria, and colonies were maintained thereafter on eggplants cv. 'Long purple' (Yates) at $20^{\circ} \mathrm{C} \pm 2{ }^{\circ} \mathrm{C}, 60 \% \pm 3 \%$ relative humidity and 14:10 light:darkness photoperiod in BugDorm-44545F insect rearing cages (BugDorm-MegaView Science, Taichung, Taiwan). Eggplant leaves with psyllids attached were removed from the plant and placed in a freezer at $-20^{\circ} \mathrm{C}$ for $24-48 \mathrm{~h}$ to kill the insects while keeping them in-situ on the leaves for ease of collection. While this freezing period may differ from field conditions, it was necessary to gather the high number of individuals required for these experiments. Once dead, the CLbr positive (CLbr+) psyllids were removed using forceps under the stereomicroscope and placed in Eppendorf screw-cap vials $(2 \mathrm{~mL}$ ) (one psyllid/vial in Experiment 1 and 10 psyllids/vial, 5 males and 5 females, in Experiment 2). Both male and female psyllids were collected for the DNA extraction method comparison (See Section 2.2) to assess sexspecific differences in bacterium presence, while only adult females were used for the PG preservation experiment (See Section 2.3). A total of 1160 psyllids were used in this study.

\subsection{Experiment 1: DNA Extraction Methods Comparison}

To determine an optimal method of DNA extraction for both insects and bacteria found in field traps, we tested ten different extraction methods covering two different DNA extraction kits, comparing destructive/non-destructive methods and different incubation periods in PG to emulate the field conditions trapped insects might be exposed to once they fall into the trap (Table 1). Each extraction method was performed on ten individual CLbr+ psyllids.

Table 1. Ten DNA extraction methods showing the combination of variables used in Experiment 1. A pre-extraction incubation in PG was performed for some methods (emulating field trap conditions), followed by DNA extraction using either the DNeasy Blood and Tissue kit (Qiagen, Qia) or the QuickExtract kit (Lucigen, QE), either destructively (D) or non-destructively (ND). Length of the incubation period in the lysis buffer and temperature of incubation is reported, together with information on the post-extraction cleanup on columns.

\begin{tabular}{|c|c|c|c|c|c|c|}
\hline \multirow[b]{2}{*}{ Method } & \multirow{2}{*}{$\begin{array}{c}\text { Pre-Extraction } \\
\text { PG Incubation } \\
\text { (Time, \%, } \\
\text { Temperature) }\end{array}$} & \multicolumn{3}{|c|}{ DNA Extraction } & \multicolumn{2}{|c|}{ Post-Extraction } \\
\hline & & Kit & $\begin{array}{c}\text { Destructive or } \\
\text { Non- } \\
\text { Destructive }\end{array}$ & $\begin{array}{c}\text { Lysis Buffer } \\
\text { Incubation (Time, } \\
\text { Temperature) }\end{array}$ & $\begin{array}{l}\text { Column } \\
\text { Clean-Up }\end{array}$ & $\begin{array}{c}\text { Lysate } \\
\text { Dilution }\end{array}$ \\
\hline 1 & No & Qia & $\mathrm{D}$ & $1 \mathrm{~h}, 56^{\circ} \mathrm{C}$ & Yes & No \\
\hline 2 & No & Qia & ND & $\mathrm{O} / \mathrm{N}, 56^{\circ} \mathrm{C}$ & Yes & No \\
\hline 3 & No & Qia & ND & $\mathrm{O} / \mathrm{N}, 56^{\circ} \mathrm{C}$ & No & No \\
\hline $3-3$ & No & Qia & ND & $\mathrm{O} / \mathrm{N}, 56^{\circ} \mathrm{C}$ & No & 1:1000 \\
\hline $3-4$ & No & Qia & ND & $\mathrm{O} / \mathrm{N}, 56^{\circ} \mathrm{C}$ & No & $1: 10,000$ \\
\hline 4 & $\mathrm{O} / \mathrm{N}, 50 \%, 23{ }^{\circ} \mathrm{C}$ & Qia & ND & $\mathrm{O} / \mathrm{N}, 56^{\circ} \mathrm{C}$ & Yes & No \\
\hline 5 & $\mathrm{O} / \mathrm{N}, 50 \%, 23{ }^{\circ} \mathrm{C}$ & Qia & ND & $\mathrm{O} / \mathrm{N}, 56^{\circ} \mathrm{C}$ & No & No \\
\hline $5-3$ & $\mathrm{O} / \mathrm{N}, 50 \%, 23{ }^{\circ} \mathrm{C}$ & Qia & ND & $\mathrm{O} / \mathrm{N}, 56^{\circ} \mathrm{C}$ & No & 1:1000 \\
\hline $5-4$ & $\mathrm{O} / \mathrm{N}, 50 \%, 23{ }^{\circ} \mathrm{C}$ & Qia & ND & $\mathrm{O} / \mathrm{N}, 56^{\circ} \mathrm{C}$ & No & $1: 10,000$ \\
\hline 6 & No & QE & $\mathrm{D}$ & $6 \mathrm{~min}, 65^{\circ} \mathrm{C}$ & No & No \\
\hline 7 & No & $\hat{\mathrm{QE}}$ & ND & $6 \mathrm{~min}, 65^{\circ} \mathrm{C}$ & No & No \\
\hline 8 & No & QE & ND & $\mathrm{O} / \mathrm{N}, 65^{\circ} \mathrm{C}$ & No & No \\
\hline 9 & $\mathrm{O} / \mathrm{N}, 50 \%, 23{ }^{\circ} \mathrm{C}$ & QE & ND & $\mathrm{O} / \mathrm{N}, 65^{\circ} \mathrm{C}$ & No & No \\
\hline 10 & $\mathrm{O} / \mathrm{N}, 50 \%, 23{ }^{\circ} \mathrm{C}$ & QE & ND & $6 \mathrm{~min}, 65^{\circ} \mathrm{C}$ & No & No \\
\hline
\end{tabular}


Method 1 (Qiagen (Qia), Destructive): For this method, DNA was destructively (D) extracted from individual psyllids using the DNeasy Blood and Tissue kit (Qiagen-Qia, Hilden, Germany). Individual psyllids were placed in $1.5 \mathrm{~mL}$ Eppendorf tubes containing two $3 \mathrm{~mm}$ solid glass beads and $20 \mu \mathrm{L}$ of proteinase $\mathrm{K}$. The insects were pulverised in a Tissuelyser (Qiagen, Hilden, Germany) at $30 \mathrm{MHz}$ for $2 \mathrm{~min}$, or until no large fragments were visible. When tubes contained no large visible fragments of insect, $180 \mu \mathrm{L}$ of ATL buffer was added, and they were incubated at $56{ }^{\circ} \mathrm{C}$ for $1 \mathrm{~h}$. After incubation, the lysate was cleaned on the filter columns provided with the kit, following the manufacturer's instructions, and finally eluted in $100 \mu \mathrm{L}$.

Method 2 (Qia, Non-destructive): DNA was non-destructively (ND) extracted from individual psyllids using the DNeasy Blood and Tissue kit following the protocol presented in [34], with an overnight incubation of $\sim 17 \mathrm{~h}$ (h) at $56^{\circ} \mathrm{C}$ followed by column cleanup of the lysate, as in Method 1.

Method 3 (Qia, ND-no filtering): DNA was non-destructively extracted from individual psyllids as per Method 2 with the following change: The lysate was used directly for qPCR, i.e., the manufacturer's protocol based on silicon-based spin columns was not used here.

Method 4 (Qia, ND-PG): As per Method 2, with the following change: psyllids were first incubated overnight $(\sim 17 \mathrm{~h})$ in a 50\% PG solution at room temperature (approximately $23^{\circ} \mathrm{C}$ ). Afterward, lysis buffer was added, followed by a second overnight incubation. The DNeasy Blood and Tissue kit manufacturer's instructions were followed thereafter.

Method 5 (Qia, ND-no filtering with PG): As per Method 4, with the following change: The lysis buffer solution was used directly for qPCR, i.e., the manufacturer's protocol based on silicon-based spin columns was not used here.

Method 6 (Quick extract (QE), destructive): DNA was destructively extracted (D) from individual psyllids using $50 \mu \mathrm{L}$ of QuickExtract ${ }^{\mathrm{TM}}$ DNA Extraction Solution (Lucigen, QE, Middleton, WI, USA). Before incubation, psyllids were lysed using the destructive bead method as per Method 1 . When tubes contained no large visible fragments of insect, they were incubated for $6 \mathrm{~min}$ at $65^{\circ} \mathrm{C}$ followed by $2 \mathrm{~min}$ at $98^{\circ} \mathrm{C}$ (manufacturer's instruction), with vortexed between incubation steps. The lysate was used directly for qPCR following the manufacturer's instructions.

Method 7 (QE, ND): DNA was non-destructively extracted from individual psyllids using the same QuickExtract buffer and incubation time as per Method 6.

Method 8 (QE, ND overnight): As per Method 7, with the following change: The initial six minutes of incubation at $65^{\circ} \mathrm{C}$ was replaced with an overnight incubation $(\sim 17 \mathrm{~h})$, followed by a 2-min incubation at $98^{\circ} \mathrm{C}$.

Method 9 (QE, ND O/N-PG): As per Method 8, with an initial overnight incubation in $50 \%$ PG and water solution followed by a QE extraction as per Method 8 .

Method 10 (QE, ND-PG): As per Method 7, with an initial incubation overnight in $50 \%$ PG and water solution followed by QE incubation times mentioned in Method 6.

To try to improve initial amplification results (see below), the DNA extracts (lysates) of methods 3 and 5 were both subsequently diluted in water 1:1000 (Methods " $3-3$ " and "5-3"; Table 1, Figure 1) and 1:10,000 (Methods "3-4" and "5-4"; Table 1; Figure 1).

\section{3. $q P C R$}

The 16S CLbr qPCR target used in this assay was from an assay designed by Morris et al. [35]. Here, a CLbr specific forward primer CLbr F (5'-TCGAGCGCGTATGTAAATACG-3'; [35]) was used in conjunction with HLBr ( $5^{\prime}$-GCGTTATCCCGTAGAAAAAGGTAG-3'; [36]) and the probe HLBp ( $5^{\prime}$-AGACGGGTGAGTAACGCG-3'; [36]). The final concentration of the forward and reverse primers was $250 \mathrm{nM}$, with a final probe concentration of $150 \mathrm{nM}$. 

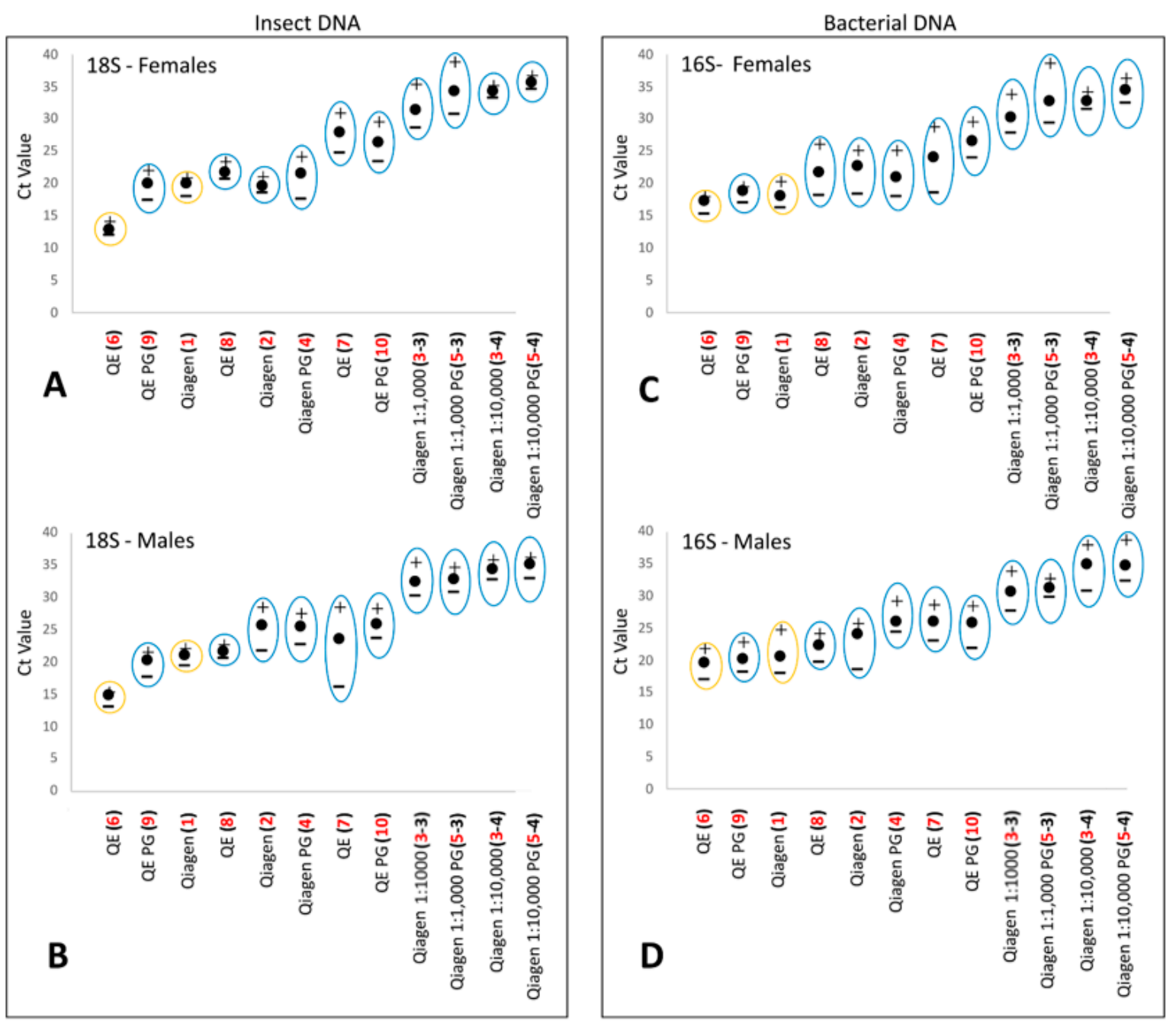

Figure 1. DNA extraction methods compared with cycle threshold (Ct) values for A. solanicola 18S ("Insect DNA"; extracted from females, (A), and males, (B)) and Candidatus Liberibacter 16S ("Bacterial DNA"; extracted from psyllid females, (C), and males, (D)). Numbers in brackets refer to the DNA extraction method numbers used in the text, while the standard kit used is indicated (Quick extract (QE)/Qiagen), with the addition of propylene glycol (PG) incubations overnight for some methods. Orange ovals indicate destructive DNA extraction methods, while blue ovals indicate non-destructive DNA extractions. Black dots are averages of five individuals, with maximum (+) and minimum (-) values reported.

The CLbr-specific target was used in multiplex with TaqMan ${ }^{\mathrm{TM}}$ Ribosomal RNA Control Reagents (Applied Biosystems, Foster City, CA, USA) targeting 18S rDNA. This commercial control kit served as an insect housekeeper control in the qPCR, with forward and reverse primers at a final concentration of $50 \mathrm{nM}$ and the probe at $200 \mathrm{nM}$ as described in the manufacturer's instructions.

The multiplex assay was performed using a real-time reverse transcription AgPath-ID ${ }^{\mathrm{TM}}$ One Step RT PCR kit (Applied Biosystems, Foster City, CA, USA) using $2 \mu \mathrm{L}$ of the template with a final reaction volume of $20 \mu \mathrm{L}$. All qPCRs were performed on a Quantstudio $3^{\mathrm{TM}}$ qPCR machine (Applied Biosystems, Foster City, CA, USA) with the following cycling conditions: $48{ }^{\circ} \mathrm{C}$ for $10 \mathrm{~min}, 95^{\circ} \mathrm{C}$ for $10 \mathrm{~min}$, and 40 cycles at $95^{\circ} \mathrm{C}$ for $15 \mathrm{~s}$ and $58^{\circ} \mathrm{C}$ for $45 \mathrm{~s}$.

\subsection{Experiment 2: Propylene Glycol DNA Preservation Time-Series Experiment}

Eppendorf screw-cap vials $(2 \mathrm{~mL})$ were filled with $10 \mathrm{CLbr}+$ adult female $A$. solanicola (adult females of similar size were chosen to minimise variation) and either $0.5 \mathrm{~mL}$ of MilliQ water or PG solutions. A total of 96 vials (960 psyllids) were prepared and divided into 16 sets, each including the six PG solution concentrations: $0 \%$ (water only), $20 \%, 40 \%, 60 \%, 80 \%$ and 
$100 \%$. The first set of vials (including each PG\% from 0 to $100 \%$ ), as well as 10 dry, frozen female psyllids (with neither PG solution nor water), was immediately frozen at $-20{ }^{\circ} \mathrm{C}$ on day 0 , for the entire duration of the experiment (28 days), serving as experimental "zero time" controls. The remaining 15 sets of vials were divided into three subsets; each kept at a different temperature: $4{ }^{\circ} \mathrm{C}, 20^{\circ} \mathrm{C}$ and $37^{\circ} \mathrm{C}$. A set of $\mathrm{PG} \%$ (six vials) was removed from each subset after 1,3,7,14 and 28 days. All vials started the experiment simultaneously and, upon reaching the end of their incubation period, were moved to $-20{ }^{\circ} \mathrm{C}$.

DNA Extraction Protocol and qPCR

Four insects from each vial were used for individual DNA extractions and qPCR analysis, with all treatments and controls extracted in parallel within 96 well microtitre plates. Wells of PCR plates were pre-loaded with $50 \mu \mathrm{L}$ of QE, and single insects were placed in each well. Based on the results obtained in the DNA extraction method comparison experiment, DNA extractions were performed following Method 8 (QE-N/D-O/N) after ensuring that the preservation in PG would not interfere with the DNA extraction, based on the results of Method 9 (QE-N/D-O/N-PG). DNA extraction plates were incubated at $65{ }^{\circ} \mathrm{C}$ overnight $(\sim 17 \mathrm{~h})$ then vortexed and incubated at $98^{\circ} \mathrm{C}$ for $2 \mathrm{~min}$ before cooling to ambient temperature and placing them at $-80{ }^{\circ} \mathrm{C}$ (manufacturer's instruction is to store QE extractions at less than $-70{ }^{\circ} \mathrm{C}$ when storing for longer than one week).

qPCRs for Experiment 2 were conducted following the methods of Experiment 1 (see Section 2.3).

\subsection{Statistical Analysis of Cycle Threshold Data}

For both experiments, psyllid and bacterium cycle threshold $(\mathrm{Ct})$ values were compared between all treatments and the controls using base $\mathrm{R}$ function for a generalised linear model (GLM) in the R software v.4.0.2. [37].

The GLM was formulated on the log-link Poisson error distribution with fixed effects, including the $\mathrm{Ct}$ values, sampling interval (days), $\mathrm{PG} \%$ and the temperature. Model residuals were checked, and the goodness of fit assessed using Pearson's Chi-square deviance test. Treatment means were compared using Tukey contrasts [38] in a general linear hypothesis (GLH) multiple comparisons procedure using the Simultaneous Inference in General Parametric Models package ("multcomp", v.1.4-13; [39]).

\section{Results}

\subsection{DNA Extraction Method Comparison}

Comparing the ten DNA extraction methods, we found that some methods resulted in lower $\mathrm{Ct}$ values while others resulted in a total lack of amplification. For example, Methods 3 and 5 (which did not include the purification steps of the extraction buffer) did not amplify either the insect or the bacterial DNA. These methods are a "crude" variant of the non-destructive Blood and Tissue kit from Qiagen, used to determine if the combination of ATL buffer and Proteinase K (PK) incubation alone (overnight at $56{ }^{\circ} \mathrm{C}$ ) was enough to detect pathogen and insect DNA. In both methods, the PK+ATL buffer mix was used directly in the qPCR without dilution or cleanup steps, resulting in a particularly crude extraction buffer generated without using any laboratory steps to remove inhibitors. When this particular DNA sample was diluted in water from 1:1000 (Methods "3-3" and "5-3", Figure 1) and 1:10,000 (Methods " $3-4$ " and "5-4", Figure 1), both the bacterium and insect could consistently be detected in all 10 extractions for Method 3 and in 9/10 extractions for Method 5. However, the Ct values recorded were $>30$ in Method 3 and $>32$ in Method 5, resulting in very late detections (Figure 1; Table S1).

On the other hand, all other DNA extraction methods enabled the amplification of both insect and bacterial DNA without requiring dilutions. When targeting insect DNA, non-destructive DNA extraction methods using the Qiagen kit (Methods 2 and 4) generated Ct values (22.65 and 23.52, respectively) that were not statistically different from those obtained using the destructive method 1 (Ct 20.48) (Figure 1; Table S1). In 
contrast, the non-destructive methods using QE (Methods 7-10) showed a statistically significant higher Ct value (25.7 and 26.16, respectively; $p<0.001)$ from that obtained using the destructive Method 6 (Ct 13.74). Amongst these, however, methods adopting a longer $\mathrm{O} / \mathrm{N}$ incubation (Methods 8 and 9, Ct 21.63 and 20.09, respectively) performed better than methods adopting a shorter 6 min incubation (Methods 7 and 10, Ct 25.7 and 26.16, respectively) (Figure 1; Table S1). For bacterial DNA, the Ct values obtained using Qiagen's non-destructive DNA extraction methods (Methods 2 and 4, Ct 23.33 and 23.37, respectively) were statistically different (albeit only marginally) from those obtained using destructive Method 1 ( $\mathrm{Ct} 19.25 ; p=0.048)$, while the non-destructive methods using the QE (Methods 8 and 9, Ct 22.02 and 19.44, respectively) resulted in a non-significant difference in $\mathrm{Ct}$ values from the destructive Method 6 (Ct 18.39). In general, non-destructive methods using QE (Methods 7-10) generated similar results for both bacterial and insect DNA to Qiagen's destructive Method (1) (GLM tests not significantly different). Furthermore, the addition of PG showed no significant difference in the Ct values obtained (GLM and Tukey's test not significant).

The average $\mathrm{Ct}$ results (males and females combined) obtained for the non-destructive Method 9 (18S: 20.093 Ct; 16S: $19.437 \mathrm{Ct}$ ) were the closest to that of the destructive Method 6 (18S: $20.484 \mathrm{Ct}$; $16 \mathrm{~S}: 19.254 \mathrm{Ct}$ ). For this reason, the relatively simple Method 8 was chosen as the preferred DNA extraction method for the PG assessment experiment.

\subsection{Controls}

The qPCR results obtained when targeting the insect DNA in the samples from day 0 (controls) were not significantly different $(p>0.05)$ for the psyllids across all PG\% producing $\mathrm{Ct}$ values between 11-13 Ct, while the psyllids that were stored dry (no solution) from day 0 showed later amplification at a mean of $17 \mathrm{Ct}$ (Figure 2). Similarly, CLbr detection across PG\% of $0-80$ was not significantly different $(p>0.05)$, ranging between $18-21 \mathrm{Ct}$, with the dry specimens also falling within this range (Figure 2). The 100\% PG storage medium resulted in the lowest $\mathrm{Ct}$ average of 14.5 and was significantly different $(p=0.021)$ from that recorded in all other solutions (Figure 2).

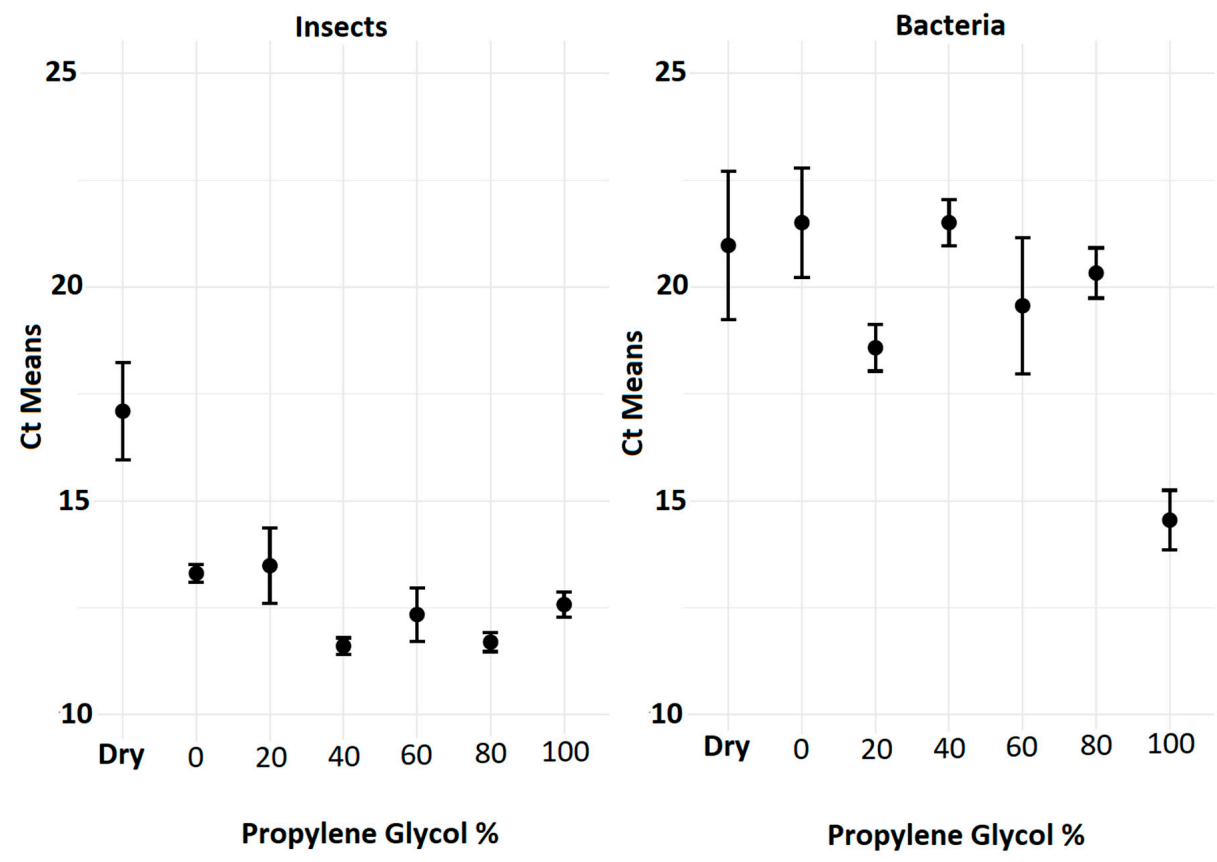

Figure 2. Plots showing the mean (dots) and standard deviation (bars) of the Cts obtained performing qPCR for A. solanicola ("insects", left) and Ca. Liberibacter ("bacteria", right) on the control vials at different $\mathrm{PG}$ solutions, frozen on day 0 of the experiment. Lower $\mathrm{Ct}$ indicates better preservation. 


\subsection{Propylene Glycol Preservation of Psyllids}

After day 1, the $18 \mathrm{~S}$ qPCR results generated $\mathrm{Ct}$ values between 13-18 with a mean of 15 and a standard deviation of 1.8 , with the higher $\mathrm{Ct}$ values (>17) produced by the psyllids stored in water (no PG) (Figure 3a). After day 3, the $18 \mathrm{~S}$ results show a larger range of $\mathrm{Ct}$ values, between $12-26 \mathrm{Ct}$ with a mean of 15 and a standard deviation of 2.9. Samples preserved at $37^{\circ} \mathrm{C}$ with no PG show a higher $\mathrm{Ct}$ average of 24.93 (Figure 3b). After day 7, the $18 \mathrm{~S}$ results show an even larger range of $\mathrm{Ct}$ values, between $11-29 \mathrm{Ct}$, with a mean of 15 and a standard deviation of 3, with the largest variation in individual sample Ct values being recorded in the 0 to $20 \%$ PG samples (Figure 3c). For day 14, the $18 \mathrm{~S} \mathrm{Ct}$ results were observed between 11-27 Ct with a mean of 15 and a standard deviation of 2.8 (Figure 3d). One $\mathrm{Ct}$ value outlier was observed in one of the replicates of the $20 \% \mathrm{PG}$ at $20{ }^{\circ} \mathrm{C}$ with a Ct of 27.8, while the other three psyllids for this treatment were between 17-19 Ct. All 0\% PG for Day 14 showed later amplification of 18 , as did some of the $20 \%$ PG results. The highest DNA preservation, as measured by low Ct values, was seen in the $40-100 \%$ PG. However, after two weeks of incubation at respective temperatures, all treatments were showing some indications of degradation, e.g., large error bars, with the greatest degradation (indicated by higher $\mathrm{Ct}$ values) being for the lowest PG \% solutions (Figure 3d). For day 28 , the $18 \mathrm{~S} \mathrm{Ct}$ results observed were between $9-31 \mathrm{Ct}$ with a mean of 16 and a standard deviation of 3.9 (Figure 3e). The greatest DNA degradation was seen at 0 to $20 \%$ PG. On the other hand, DNA from samples with PG above $40 \%$ was always preserved to a similar level (Figure 3e).

The GLM confirmed that, for the psyllid 18S, both the temperature treatments and the PG\% were statistically significantly different. With all PG $\%$ from $20 \%$ to $100 \%$ being significantly different from PG $0 \%$, with $p<0.001$, while both $20^{\circ} \mathrm{C}$ and $37^{\circ} \mathrm{C}$ temperatures were significantly different from $4{ }^{\circ} \mathrm{C}$, with $p=0.018$ and $p=0.002$, respectively. On the other hand, the only statistically different time period was observed between day 1 and day $28(p=0.042)$. A post-hoc Tukey's contrast test was conducted to determine if a significant effect could be recorded between any of the individual factors analysed (incubation time, PG\%, temperature). There were no statistically significant differences found overall across different incubation periods (days). Similarly, variation in the incubation temperature resulted in only slight statistical significance when comparing the specimens kept at $20^{\circ} \mathrm{C}$ and $4{ }^{\circ} \mathrm{C}(p=0.047)$, and partially stronger when comparing those kept at $37^{\circ} \mathrm{C}$ and $4{ }^{\circ} \mathrm{C}$ (0.007); however, no significant variation was recorded between $20^{\circ} \mathrm{C}$ and $37^{\circ} \mathrm{C}$ $(p=0.772)$. On the other hand, statistically significant differences were recorded for any PG\% compared against water (PG\%=0), with all $\mathrm{PG} \%$ between $40 \%$ and $100 \%$ showing a $p<0.001$, while $20 \%$ had a $p=0.01$. Furthermore, the $\mathrm{Ct}$ values of all samples preserved at a PG $\%>20 \%$ were also significantly lower than those preserved in $20 \%$ PG ( $p$ ranging from $<0.001$ to 0.046 ). On the other hand, no significant differences were recorded between samples preserved at $40 \%, 60 \%, 80 \%$ or $100 \%$. 


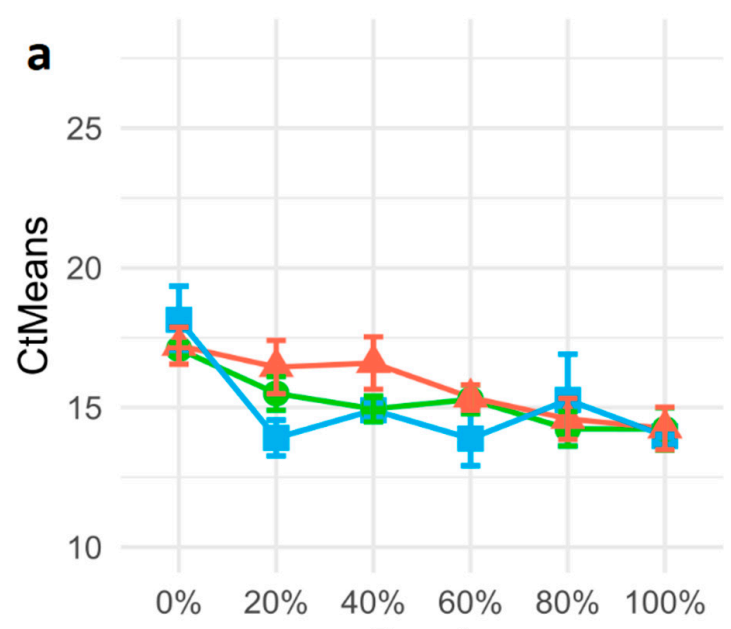

Day 1

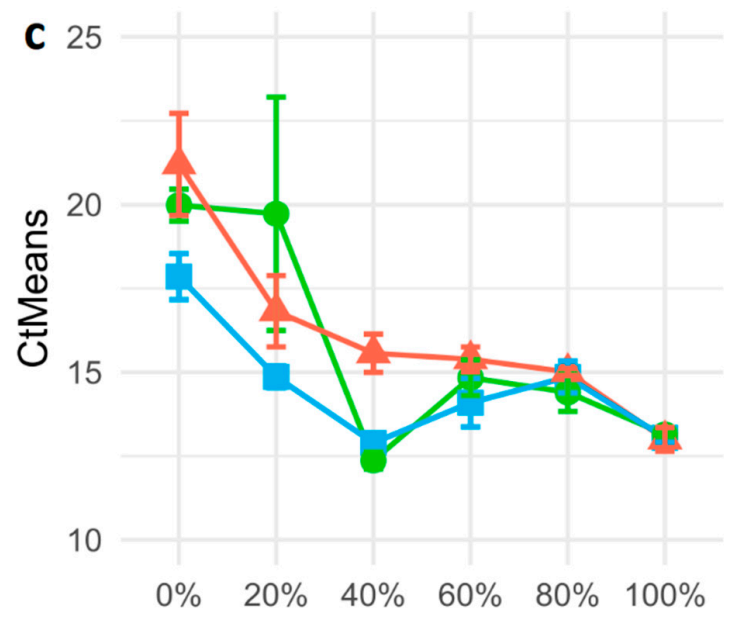

Day 7

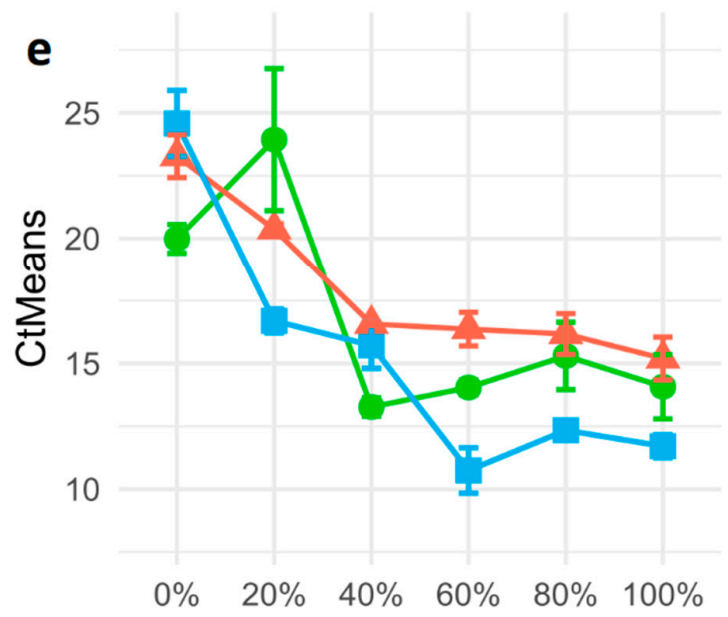

Day 28

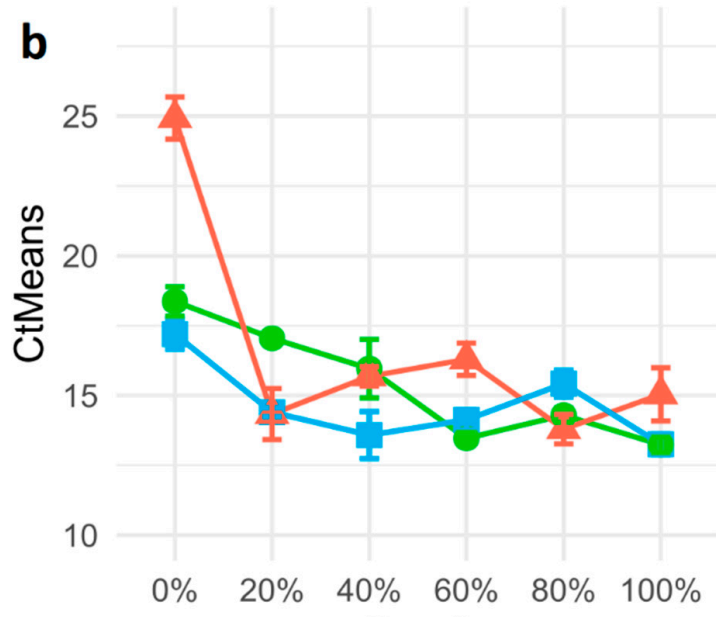

Day 3

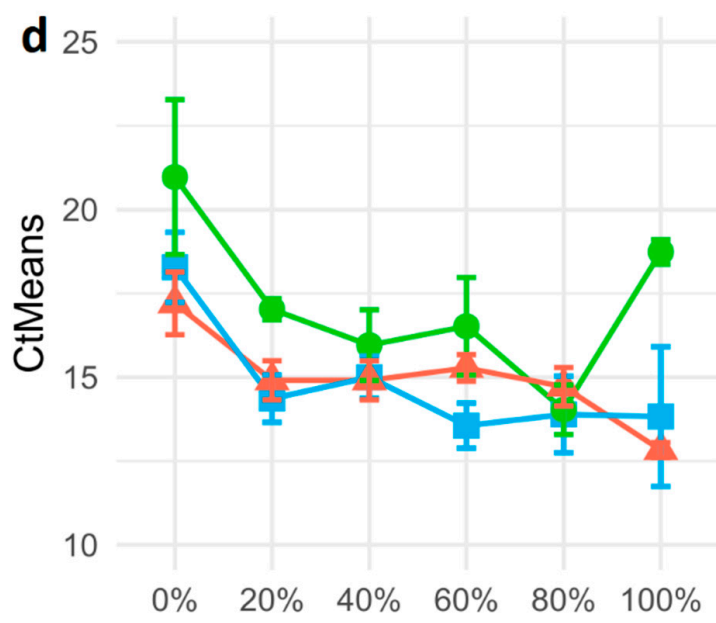

Day 14

\section{Temperatures}

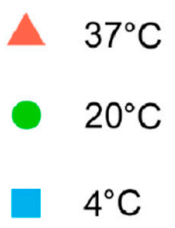

$4^{\circ} \mathrm{C}$

Figure 3. Plots showing the quantitative polymerase chain reaction (qPCR) results obtained from analysing the psyllid samples. Each plot represents the results obtained at different time points: day 1 (a), day 3 (b), day 7 (c) day 14 (d) and day 28 (e). The different colours represent the incubation temperatures. For each plot, six PG\% solutions are shown while each dot is the mean of four individual single psyllid specimens, while the bars represent the standard deviation. Lower $\mathrm{Ct}$ indicates better preservation. 


\subsection{Propylene Glycol Preservation of Ca. Liberibacter DNA}

On day 1, CLbr was detected in all psyllid treatments, with Cts ranging between 13 and 28 and a mean of 19 with a standard deviation of 3.622. When analysed by PG\% (with all the temperature results pooled), $20 \%$ and $100 \%$ PG show earliest amplification and $0 \%$ and $80 \%$ PG amplifying at later cycles (Figure 4). On day 3, CLbr detection across all psyllid treatments ranged between 12 and $27 \mathrm{Ct}$ with a mean of 18.5 and a standard deviation of 3.7. When analysed by PG\% (with all the temperature results pooled) 40 and $60 \%$ PG show earliest amplification and 0\% PG amplifying later. On day 3, a trend starts to form for data by temperature, with $4{ }^{\circ} \mathrm{C}$ showing a lower average $\mathrm{Ct}$ for each target compared to 20 and $37^{\circ} \mathrm{C}$ (Figure $4 \mathrm{~b}$ ). On day 7, CLbr detection across all psyllid treatments was between 13 and $31 \mathrm{Ct}$ with a mean of $19 \mathrm{Ct}$ and a standard deviation of 4 . A temperature trend is more pronounced with an overall average of $16.8 \mathrm{Ct}$ for $4{ }^{\circ} \mathrm{C}$ treatments, $18.9 \mathrm{Ct}$ for $20^{\circ} \mathrm{C}$ treatments and $21.1 \mathrm{Ct}$ for $37^{\circ} \mathrm{C}$, which is approximately a 10 -fold decrease in CLbr between 37 and $20^{\circ} \mathrm{C}$ and over a 15 -fold reduction between 37 and $4{ }^{\circ} \mathrm{C}$ (Figure 4). On day 14, CLbr detection across all psyllid treatments was between 13 and $30 \mathrm{Ct}$ with a mean of $20 \mathrm{Ct}$ and a standard deviation of 3.4. The samples incubated at $20^{\circ} \mathrm{C}$ amplified Ca. Liberibacter DNA later than at $37^{\circ} \mathrm{C}$ with the earliest amplification seen across the $4{ }^{\circ} \mathrm{C}$ incubations (Figure 4). Ultimately, on day 28, CLbr detection across all psyllid treatments was between $12-38 \mathrm{Ct}$ with a mean of $19 \mathrm{Ct}$ and a standard deviation of 3.9. When analysed by PG\% (with all the temperature results pooled), the best preservation of CLbr DNA was from $40-80 \%$ PG. The temperature effect was not obvious by day 28 , with only small variations in $\mathrm{Ct}$ observed (Figure 4e).

The GLM confirmed that, for the Ca. Liberibacter 16S, both the temperature treatments and the PG\% were statistically significantly different. All PG $\%$ from $20 \%$ to $100 \%$ being strongly different from PG $0 \%$, with $p<0.001$, while both $20^{\circ} \mathrm{C}$ and $37^{\circ} \mathrm{C}$ temperatures were significantly different from $4{ }^{\circ} \mathrm{C}$, with $p=0.007$ and $p=0.002$, respectively. In Tukey's contrast test, there were no statistically significant differences found between different incubation periods (days). Similar to the psyllid DNA, variation in the incubation temperature resulted only slightly statistically significant when comparing the specimens kept at $20^{\circ} \mathrm{C}$ and $4{ }^{\circ} \mathrm{C}(p=0.019)$, and partially stronger when comparing those kept at $37^{\circ} \mathrm{C}$ and $4{ }^{\circ} \mathrm{C}(0.005)$; however, no significant differences were recorded between $20^{\circ} \mathrm{C}$ and $37^{\circ} \mathrm{C}(p=0.888)$. A statistically significant difference was found between the different PG\% compared to water $(p<0.001)$. However, no statistical differences were found between samples preserved in $20 \%, 40 \%, 60 \%, 80 \%$ or $100 \%$ PG. 


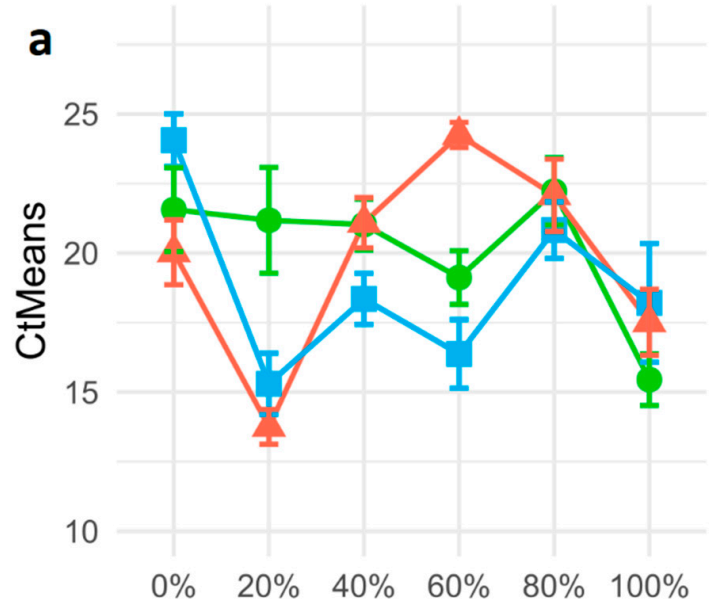

Day 1

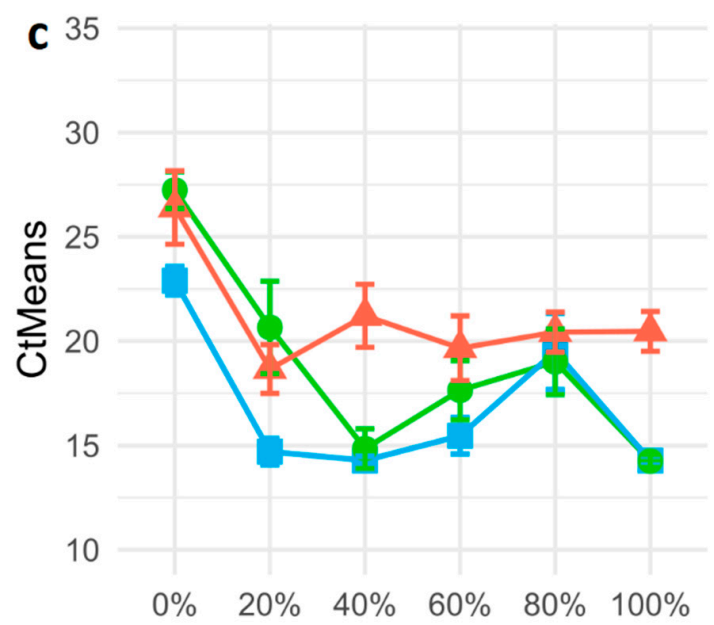

Day 7

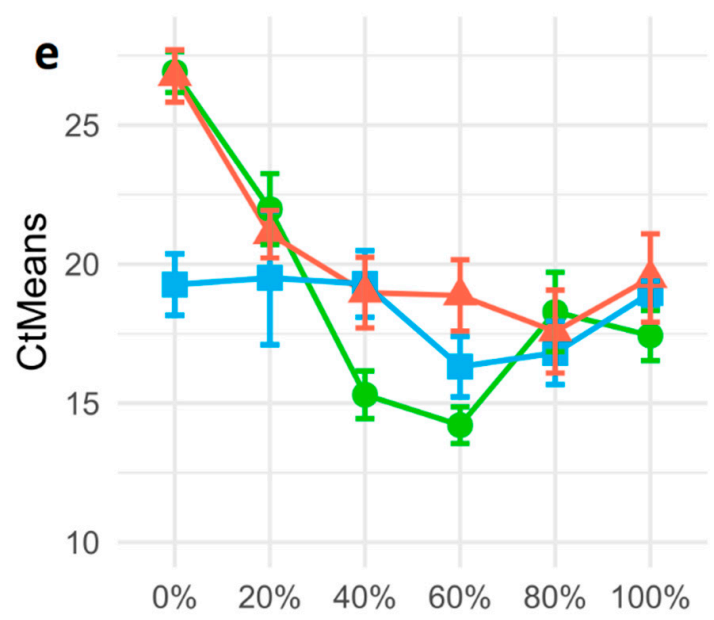

Day 28

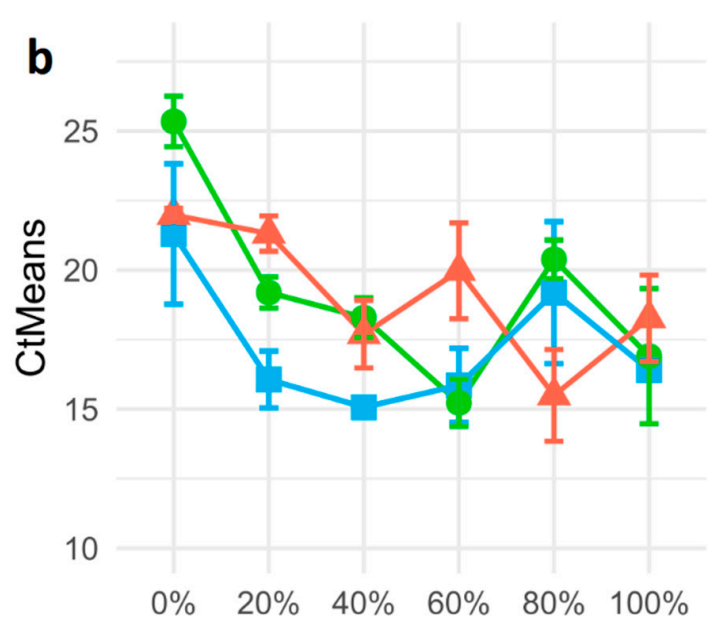

Day 3

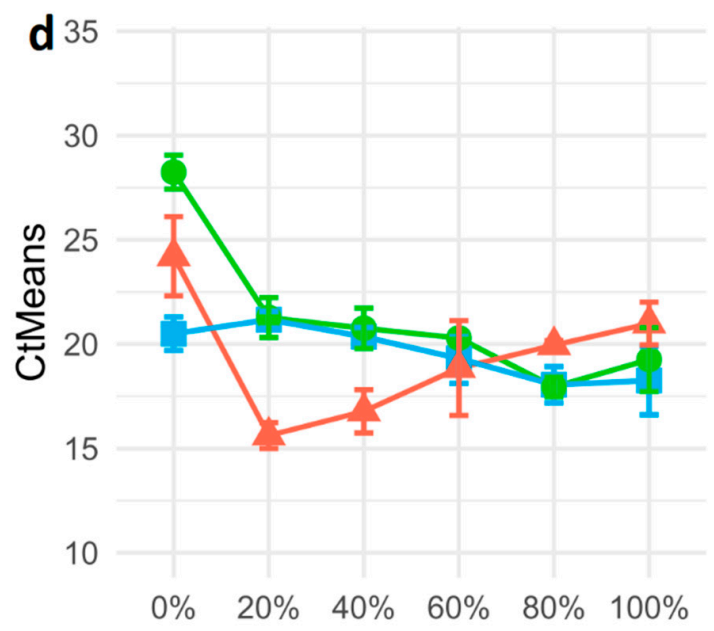

Day 14

\section{Temperatures}

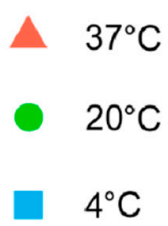

Figure 4. Plots showing the qPCR results obtained from analysing the bacterial samples. Each plot represents the results obtained at different time points: day 1 (a), day 3 (b), day 7 (c) day 14 (d) and day 28 (e). The different colours represent the incubation temperatures. For each plot, six PG\% solutions are shown, with each dot representing the mean of four individual single psyllid specimens and each bar representing the standard deviation. Lower Ct indicates better preservation. 


\section{Discussion}

The importance of DNA preservation for molecular-based studies aiming to detect and identify trapped insects is paramount, and DNA preservatives have been tested for different insect groups and to accommodate different needs [8]. For example, ethanol solutions ranging from $70-80 \%$ (for short-term preservation) to $90-100 \%$ (for long-term preservation) are widely considered to be one of the best methods [10,13]. However, ethanol tends to evaporate at higher temperatures [21], and its flammability does not readily allow shipping from the field to the laboratory. Similarly, freezing at $-80^{\circ} \mathrm{C}$ and $-150{ }^{\circ} \mathrm{C}$ [11], both extremely valid DNA preservation methods, require technology/appliances that often cannot be used in the field. Even dry storage of specimens, known to be a valid tool to preserve insect DNA [40], can be problematic in high-moisture, humid environments. For these reasons, we tested the qualities of propylene glycol as a non-flammable, easily transportable and ready-to-use DNA preservative that can be deployed in remote areas for trapping both insects and bacteria.

Non-destructive DNA extraction techniques for insects have been widely adopted for the molecular detection and identification of insects [41-44] and retaining specimens for ID confirmation using morphological features or inclusion in reference collections is particularly important (e.g., $[29,34])$. However, to date, these non-destructive DNA extraction studies have only focused on the insects and not their associated bacteria. Hence, we used this technique to focus on a psyllid host/vectored bacterium system using an A. solanicola colony infected with the non-pathogenic bacterium $\mathrm{Ca}$. L. brunswickensis as a model. Considering the presence of a number of plant pathogenic bacteria within the genus Ca. Liberibacter (e.g., [4,32,45]), the application of this method can allow retention of morphological voucher specimens of the host psyllid, possibly enabling future research and additional analyses to understand both the host and the pathogen ecology better.

The results obtained in the DNA extraction method comparison experiment demonstrated that every non-destructive DNA extraction method tested (2-5 and 7-10) allowed the detection of both the insect and its vectored bacteria, albeit at different qPCR Cts, suggesting differences in the relative yield of DNA and/or abundance of PCR inhibitors. For example, amongst the non-destructive methods using the Qiagen kit (2-5), Methods 2 and 4 (average Cts: $18 \mathrm{~S}=22.665$ and 23.522; $16 \mathrm{~S}=23.332$ and 23.372, respectively; Table S1) performed better than Methods 3 and 5 (average Cts not recorded unless the extract was diluted; Table S1). Similarly, amongst non-destructive methods using the QE kit (7-10), Methods 8 and 9 (average Cts: $18 \mathrm{~S}=21.635$ and 20.093; $16 \mathrm{~S}=22.022$ and 19.437, respectively; Table S1) outperformed Methods 7 and 10 (average Cts: $18 \mathrm{~S}=25.7$ and 26.163; $16 \mathrm{~S}=25.011$ and 26.224, respectively; Table S1). Despite these variations in Ct values, all methods allowed the recording of the presence/absence of both insect and bacterial DNA. This result per se suggests that even when targeting detection of a $\mathrm{Ca}$. Liberibacter species, there is no need for destructive DNA extraction. Furthermore, both Lucigen's QuickExtract kit and Qiagen's Blood and Tissue kit generated a robust result even when the insects were preserved in propylene glycol before the extraction (Methods 4 and 9), suggesting that this preservative agent does not interfere with the DNA extraction methods.

Ultimately, Method 8 was chosen as the non-destructive DNA extraction method for our large-scale DNA preservation experiment, as it was a very simple laboratory procedure that performed well, providing strong results even when an extended PG incubation step was included (Method 9). For this reason, our experiments quantification of DNA was performed through real-time PCR, using the comparative Ct method [33], as other methods of quantification were not considered reliable for QE DNA extractions, which are known to retain residual degraded DNA in the sample impeding an accurate quantification using spectrophotometric methods and generating an artificially high estimate of the DNA concentration [46].

Our large-scale DNA preservation experiment showed that PG concentrations between $40 \%$ and $100 \%$ consistently preserve psyllid DNA, with a statistically significant increase in the DNA obtained (lower Ct values) compared with PG concentrations between $0 \%$ and 
$20 \%$. This highlights the role of PG as a strong preservative agent for insect DNA, effective even at concentrations as low as $40 \%$. Additionally, psyllid DNA preservation was not significantly influenced by different temperatures and periods of incubation. Even extreme temperature conditions (i.e., constant $37^{\circ} \mathrm{C}$ ) combined with low PG\%'s over extended time periods, up to 28 days, did not greatly alter the effect of PG on DNA preservation.

Similarly, the analysis of the (frozen) insect DNA controls showed very little degradation even with specimens preserved in water since the freezing temperature played a major role in the preservation. When observing the dry, frozen controls, we observed a more variable insect DNA preservation, ranging between a $\mathrm{Ct}$ value of 12.99 and 20.21. Given the nature of psyllids—small-bodied, lightweight insects—such a Ct variability might be due to the fact the dry specimen might not have sunk completely in the QE buffer during the DNA extraction process. All controls preserved in a liquid medium remained heavy enough to sink in the QE buffer, showing a lower Ct value when analysed using the qPCR. This suggests that PG can be used over extended periods in challenging environmental conditions to preserve hemipteran DNA.

When considering the $\mathrm{Ca}$. Liberibacter DNA, the results showed a much more variable trend compared to the insect DNA. While CLbr DNA could be detected from all samples, it did not show a clear pattern of preservation across different PG solutions, temperatures or times. For example, lower temperatures appeared to preserve CLbr DNA better on day 7 but showed worse preservation at days 14 and 28. Similarly, at days 7 and 14, lower $\mathrm{Ct}$ values were recorded for PG concentrations of $20 \%$, while on day 28 , the lowest $\mathrm{Ct}$ value was recorded for a PG concentration of $60 \%$. Such variable and inconsistent results matched those obtained in the controls, with dry controls and solutions of PG from $0 \%$ to $80 \%$ generating extremely similar Ct values, while the $100 \%$ PG solution showed the higher preservation.

A possible reason for this inconsistent pattern might suggest that the variability in $\mathrm{Ct}$ values of the CLbr qPCR results are not linked to any of the factors we tested here. Instead, this might be due to the variable titres of CLbr present in each psyllid before the incubation periods in PG. While the psyllids were raised in a CLbr positive colony, the concentration of $\mathrm{Ca}$. Liberibacter is known to fluctuate between different individuals [30], making it impossible to estimate CLbr titre in individual insects. Hence, while similarly body-sized psyllids of the same sex were selected to minimise biases in the insect DNA concentration, it was not possible to do the same for the $C a$. Liberibacter DNA. Nonetheless, despite not knowing the precise concentration of CLbr in individual CLbr+ psyllids before the experiment, the results obtained here show that $\mathrm{Ca}$. Liberibacter DNA was consistently detected across all temperatures and time periods. This demonstrates, for the first time, that CLbr DNA is well preserved in solutions of PG between $40 \%$ and $100 \%$ and can be successfully detected using a non-destructive DNA extraction method even after a month at $37^{\circ} \mathrm{C}$.

While both insect and bacterial DNA could be detected consistently from PG concentrations ranging between $40 \%$ and 100\%, we recommend concentrations between $40 \%$ and $60 \%$ for application in insect traps. This takes into consideration not only the more stable range of preservation (40-100\%) but also the mechanical issues that a higher PG concentration might entail. Higher concentrations of PG (80-100\%) tend to be a viscous solution. Indeed, the absolute viscosity of PG (0.042) is approximately 40 times higher than that of ethanol (0.001095) at room temperature while being subject to density and viscosity variations at higher temperatures and pressures [47]. Viscosity and surface tension at high PG\% risk preventing insects from effectively sinking into the preservative, leaving them exposed or partially exposed to environmental factors that would degrade the DNA. This viscosity can pose a further challenge when filtering or removing insects from high PG\% solutions, with slow filtering seen when using filters with pores that are smaller than $200 \mu \mathrm{m}$ (Martoni 2020, personal observation). Therefore, our suggested PG\% between 40\% and $60 \%$ enhances DNA preservation by allowing the insects to sink into the solution and also optimises downstream processing of the trapped specimens. 
In conclusion, the results presented here support the use of propylene glycol as a preservative paired with non-destructive DNA extraction techniques within biosecurity surveillance for both invasive insect pests as well as the pathogenic bacteria they vector. These findings will provide confidence for surveillance programs targeting multi-kingdom insect and pathogen systems in remote areas and improve crop health and biosecurity. Furthermore, the techniques adopted here are scalable and can be used for high throughput sequencing of insect and bacterial DNA, enabling the preservation and extraction of DNA from bulk traps while retaining a morphological voucher that can be associated with the DNA sequences obtained as required for metabarcoding techniques [8].

Supplementary Materials: The following are available online at https:/ /www.mdpi.com/2077-047 2/11/1/77/s1, Table S1: Summary of the qPCR performed on the DNA extractions products of 10 psyllids (five males and five females). qPCR tested both for bacterial DNA (16S gene) and for the psyllid DNA (18S gene).

Author Contributions: Conceptualisation, all authors; methodology, all authors; formal analysis, F.M., E.N. and A.M.P.; investigation, F.M. and E.N.; resources, M.J.B. and B.C.R.; data curation, F.M.; writing — original draft preparation, F.M.; writing—review and editing, all authors; funding acquisition, M.J.B. and B.C.R. All authors have read and agreed to the published version of the manuscript.

Funding: This research was funded by the Australian Government Department of Agriculture, Horticulture Innovation Australia (ST16010) and Grains Research and Development Corporation.

Acknowledgments: The authors would like to thank the iMapPESTS project, supported by Horticulture Innovation Australia (ST16010) through funding from the Australian Government Department of Agriculture as part of its Rural R\&D for Profit program and Grains Research and Development Corporation, for funding these experiments and the publication of this article. Many thanks to Jacqueline Morris for enabling the authors to use the psyllid colonies she originally maintained. Thanks to Aimee Claire McKinnon for useful comments and suggestions on a previous version of this manuscript.

Conflicts of Interest: The authors declare no conflict of interest.

\section{References}

1. Liebhold, A.M.; Berec, L.; Brockerhoff, E.G.; Epanchin-Niell, R.S.; Hastings, A.; Herms, D.A.; Kean, J.M.; McCullough, D.G.; Suckling, D.M.; Tobin, P.C.; et al. Eradication of invading insect populations: From concepts to applications. Annu. Rev. Entomol. 2016, 61, 335-352. [CrossRef] [PubMed]

2. Trebitz, A.S.; Hoffman, J.C.; Darling, J.A.; Pilgrim, E.M.; Kelly, J.R.; Brown, E.A.; Chadderton, W.L.; Egan, S.P.; Grey, E.K.; Hashsham, S.A.; et al. Early detection monitoring for aquatic non-indigenous species: Optimizing surveillance, incorporating advanced technologies, and identifying research needs. J. Environ. Manag. 2017, 202, 299-310. [CrossRef] [PubMed]

3. Weintraub, P.G.; Beanland, L. Insect vectors of phytoplasmas. Annu. Rev. Entomol. 2006, 51, 91-111. [CrossRef] [PubMed]

4. Liefting, L.W.; Sutherland, P.W.; Ward, L.I.; Paice, K.L.; Weir, B.S.; Clover, G.R.G. A new "Candidatus Liberibacter" species associated with diseases of Solanaceous crops. Plant Dis. 2009, 93, 208-214. [CrossRef]

5. Overall, L.M.; Rebek, E.J. Insect vectors and current management strategies for diseases caused by Xylella fastidiosa in the Southern United States. J. Integr. Pest Manag. 2017, 8, 12. [CrossRef]

6. Vereijssen, J.; Smith, G.R.; Weintraub, P.G. Bactericera cockerelli (Hemiptera: Triozidae) and Candidatus Liberibacter solanacearum in potatoes in New Zealand: Biology, transmission, and implications for management. J. Integr. Pest Manag. 2018, 9, 1-21. [CrossRef]

7. Lodge, D.M.; Williams, S.; MacIsaac, H.J.; Hayes, K.R.; Leung, B.; Reichard, S.; Mack, R.N.; Moyle, P.B.; Smith, M.; Andow, D.A.; et al. Biological invasions: Recommendations for U.S. policy and management. Ecol. Appl. 2006, 16, 2035-2054. [CrossRef]

8. Piper, A.M.; Batovska, J.; Cogan, N.O.; Weiss, J.; Cunningham, J.P.; Rodoni, B.C.; Blacket, M.J. Prospects and challenges of implementing DNA metabarcoding for high throughput insect surveillance. GigaScience 2019, 8, giz092. [CrossRef]

9. Martin, J.E.H. The Insects and Arachnids of Canada. Part 1: Collecting, Preparing, and Preserving Insects, Mites, and Spiders; Canada Department of Agriculture: Ottawa, ON, Canada, 1977; p. 182.

10. Stein, E.D.; White, B.P.; Mazor, R.D.; Miller, P.E.; Pilgrim, E.M. Evaluating ethanol-based sample preservation to facilitate use of DNA barcoding in routine freshwater biomonitoring programs using benthic macroinvertebrates. PLoS ONE 2013,8, e51273. [CrossRef]

11. Hammer, T.J.; Dickerson, J.C.; Fierer, N. Evidence-based recommendations on storing and handling specimens for analyses of insect microbiota. PeerJ 2015, 3, e1190. [CrossRef] 
12. Robinson, C.V.; Porter, T.M.; Wright, M.T.G.; Hajibabaei, M. Propylene glycol-based antifreeze as an effective preservative for DNA metabarcoding of benthic arthropods. bioRxiv 2020. [CrossRef]

13. Marquina, D.; Ronquist, F.; Łukasik, P. The effect of ethanol concentration on the preservation of insects for biodiversity studies. bioRxiv 2020. [CrossRef]

14. Nakamura, S.; Tamura, S.; Taki, H.; Shoda-Kagaya, E. Propylene glycol: A promising preservative for insects, comparable to ethanol, from trapping to DNA analysis. Entomol. Exp. Appl. 2020, 168, 158-165. [CrossRef]

15. Matos-Maraví, P.; Ritter, C.D.; Barnes, C.J.; Nielsen, M.; Olsson, U.; Wahlberg, N.; Marquina, D.; Sääksjärvi, I.; Antonelli, A. Biodiversity seen through the perspective of insects: 10 simple rules on methodological choices and experimental design for genomic studies. PeerJ 2019, 7, e6727. [CrossRef]

16. Gurdebeke, S.; Maelfait, J.-P. Pitfall trapping in population genetics studies: Finding the right "solution". J. Arachnol. 2002, 30, 255-261. [CrossRef]

17. Moreau, C.S.; Wray, B.D.; Czekanski-Moir, J.E.; Rubin, B.E.R. DNA preservation: A test of commonly used preservatives for insects. Invertebr. Syst. 2013, 27, 81-86. [CrossRef]

18. Pokluda, P.; Čižek, L.; Stříbrná, E.; Drag, L.; Lukeš, J.; Novotný, V. A goodbye letter to alcohol: An alternative method for field preservation of arthropod specimens and DNA suitable for mass collecting methods. Eur. J. Entomol. 2014, 111, 175-179. [CrossRef]

19. Ballare, K.M.; Pope, N.S.; Castilla, A.R.; Cusser, S.; Metz, R.P.; Jha, S. Utilizing field collected insects for next generation sequencing: Effects of sampling, storage, and DNA extraction methods. Ecol. Evol. 2019, 9, 13690-13705. [CrossRef]

20. Nagy, Z.T. A hands-on overview of tissue preservation methods for molecular genetic analyses. Org. Divers. Evol. 2010, 10, 91-105. [CrossRef]

21. Aristophanous, M. Does your preservative preserve? A comparison of the efficacy of some pitfall trap solutions in preserving the internal reproductive organs of dung beetles. Zookeys 2010, 34, 1-16. [CrossRef]

22. Rubink, W.L.; Murray, K.D.; Baum, K.A.; Pinto, M.A. Long term preservation of DNA from honey bees (Apis mellifera) collected in aerial pitfall traps. Texas J. Sci. 2003, 55, 159-168.

23. Vink, C.J.; Thomas, S.M.; Paquin, P.; Hayashi, C.Y.; Hedin, M. The effects of preservatives and temperatures on arachnid DNA. Invertebr. Syst. 2005, 19, 99-104. [CrossRef]

24. Stevens, M.M.; Warren, G.N.; Mo, J.; Schlipalius, D.I. Maintaining DNA quality in stored-grain beetles caught in Lindgren funnel traps. J. Stored Prod. Res. 2011, 47, 69-75. [CrossRef]

25. Ferro, M.L.; Park, J.S. Effect of propylene glycol concentration on mid-term DNA preservation of Coleoptera. Coleopt. Bull. 2013, 67, 581-586. [CrossRef]

26. Schutze, M.K. Propylene glycol as an effective preservation agent for subsequent genetic analysis of trap-caught fruit flies. Fruit Flies News 2012, 23, 1-2.

27. Patrick, H.J.H.; Chomič, A.; Armstrong, K.F. Cooled propylene glycol as a pragmatic choice for preservation of DNA from remote field-collected Diptera for next-generation sequence analysis. J. Econ. Entomol. 2016, 109, 1469-1473. [CrossRef] [PubMed]

28. Sokolova, Y.Y.; Sokolov, I.M.; Carlton, C.E. New microsporidia parasitizing bark lice (Insecta: Psocoptera). J. Invertebr. Pathol. 2010, 104, 186-194. [CrossRef]

29. Martoni, F.; Valenzuela, I.; Blacket, M.J. On the complementarity of DNA barcoding and morphology to distinguish benign endemic insects from possible pests: The case of Dirioxa pornia and the tribe Acanthonevrini (Diptera: Tephritidae: Phytalmiinae) in Australia. Insect Sci. 2020. [CrossRef]

30. Morris, J.; Shiller, J.; Mann, R.; Smith, G.; Yen, A.; Rodoni, B. Novel ‘Candidatus Liberibacter' species identified in the Australian eggplant psyllid, Acizzia solanicola". Microb. Biotechnol. 2017, 10, 833-844. [CrossRef]

31. Kent, D.S.; Taylor, G.S. Two new species of Acizzia Crawford (Hemiptera: Psyllidae) from the Solanaceae with a potential new economic pest of eggplant, Solanum melongena. Aust. J. Entomol. 2010, 49, 73-81. [CrossRef]

32. Jagoueix, S.; Bove, J.M.; Garnier, M. The phloem-limited bacterium of greening disease of citrus is a member of the alpha subdivision of the Proteobacteria. Int. J. Syst. Evol. Microbiol. 1994, 44, 379-386. [CrossRef]

33. Schmittgen, T.; Livak, K. Analyzing real-time PCR data by the comparative CT method. Nat. Protoc. 2008, 3, 1101-1108. [CrossRef] [PubMed]

34. Martoni, F.; Valenzuela, I.; Blacket, M.J. Non-destructive DNA extractions from fly larvae (Diptera: Muscidae) enable molecular identification of possible pests and enhance morphological features. Austral Entomol. 2019, 58, 848-856. [CrossRef]

35. Morris, J.; Mann, R.; Sanka Perera, A.; Frampton, R.; Malipatil, M.; Norng, S.; Yen, A.; Smith, G.; Rodoni, B. ‘Candidatus Liberibacter brunswickensis' colonization has no effect to the early development of Solanum melongena. Mol. Plant Microbe Interact. J. 2021. under review.

36. Li, W.; Hartung, J.S.; Levy, L. Quantitative real-time PCR for detection and identification of Candidatus Liberibacter species associated with citrus huanglongbing. J. Microbiol. Methods 2006, 66, 104-115. [CrossRef]

37. R Core Team. R: A Language and Environment for Statistical Computing; R Foundation for Statistical Computing: Vienna, Austria, 2020; Available online: https:/ / www.R-project.org/ (accessed on 1 December 2020).

38. Tukey, J. Comparing individual means in the analysis of variance. Biometrics 1949, 5, 99-114. [CrossRef]

39. Bretz, F.; Hothorn, T.; Westfall, P. Multiple Comparisons Using R; Chapman and Hall/CRC: Boca Raton, FL, USA, $2010 ;$ p. 208. 
40. Nakahama, N.; Isagi, Y.; Ito, M. Methods for retaining well-preserved DNA with dried specimens of insects. Eur. J. Entomol. 2019, 116, 486-491. [CrossRef]

41. Favret, C. A new non-destructive DNA extraction and specimen clearing technique for aphids (Hemiptera). Proc. Entomol. Soc. Wash. 2005, 107, 469-470.

42. Gilbert, M.T.P.; Moore, W.; Melchior, L.; Worobey, M. DNA extraction from dry museum beetles without conferring external morphological damage. PLoS ONE 2007, 2, e272. [CrossRef]

43. Porco, D.; Rougerie, R.; Deharveng, L.; Hebert, P. Coupling non-destructive DNA extraction and voucher retrieval for small soft-bodied arthropods in a high-throughput context: The example of Collembola. Mol. Ecol. Resour. 2010, 10, 942-945. [CrossRef]

44. Bahder, B.W.; Bollinger, M.L.; Sudarshana, M.R.; Zalom, F.G. Preparation of mealybugs (Hemiptera: Pseudococcidae) for genetic characterization and morphological examination. J. Insect Sci. 2015, 15, 104. [CrossRef] [PubMed]

45. Munyaneza, J.E.; Sengoda, V.G.; Sundheim, L.; Meadow, R. Survey of "Candidatus Liberibacter solanacearum" in carrot crops affected by the psyllid Trioza apicalis (Hemiptera: Triozidae) in Norway. J. Plant Pathol. 2014, 96, 397-402. [CrossRef]

46. Lucigen. Frequently asked questions-QuickExtract ${ }^{\mathrm{TM}}$ DNA Extraction Solution and QuickExtract ${ }^{\mathrm{TM}}$ FFPE DNA Extraction Kit. 2020. Available online: https:/ / www.lucigen.com/docs/faqs/FAQ-QuickExtract-DNA-Solution.pdf (accessed on 1 December 2020).

47. Sagdeev, D.I.; Fomina, M.G.; Abdulagatov, I.M. Density and viscosity of propylene glycol at high temperatures and high pressures. Fluid Phase Equilib. 2017, 450, 99-111. [CrossRef] 